\section{Australian Journal of \\ Crop Science}

AJCS

ISSN:1835-2707

AJCS 14(01):64-70 (2020)

doi: 10.21475/ajcs.20.14.01.p1843

\title{
Simulation of scenarios considering different stump and pre-bucking disc heights in mechanized timber harvesting operations in Pinus spp. stands after the fourth thinning
}

\author{
Gustavo Silva Oliveira ${ }^{1 *}$, Philipe Ricardo Casemiro Soares ${ }^{2}$, Jean Alberto Sampietro ${ }^{2}$, Maycon Thuan \\ Saturnino da Silva ${ }^{1}$, Marcos Felipe Nicoletti ${ }^{2}$, Chaiane Rodrigues Schneider ${ }^{1}$, Thiago Floriani Stepka ${ }^{2}$, Julio \\ Peretti da Silva².
}

${ }^{1}$ Department of Forestry Sciences, Federal University of Paraná - UFPR, Curitiba, Paraná, Brazil
${ }^{2}$ Department of Forest Engineering, University of the State of Santa Catarina - UDESC, Lages, Santa Catarina, Brazil

*Corresponding author: gustavo_ccp@hotmail.com

\begin{abstract}
This study aimed to quantify scenarios, considering different stump and pre-bucking disc heights, in order to search for alternatives to optimize the mechanized timber harvesting process in a Pinus spp. forest. In this way, the simulation of six scenarios was carried out after the fourth thinning. The situation defined by the company in its planning was considered and applied to scenario 1 (S1), with stump heights and pre-bucking disc heights of up to $15 \mathrm{~cm}$ and $10 \mathrm{~cm}$, respectively. The scenario 2 (S2) included the real situation, that is, the measurements made in sample units installed on the field, scenario 3 (S3) included stump heights of $10 \mathrm{~cm}$ and pre-bucking disc heights of $5 \mathrm{~cm}$ and, in the other scenarios (S4, S5 and S6), stump and pre-bucking disc heights with values higher than the ones specified by the company were included. To that end, taper functions were used to quantify the assortments and the economic returns for each scenario. Results showed that scenario 3 presented the highest economic gain (5434.27 USD ha1) followed by scenario 2 (5431.97 USD ha-1), surpassing the production expectations (S1). Therefore, the company must seek to improve and optimize the mechanized harvesting process by increasing investments for improvements in the planning of the operations, establishing measures throughout the production process and training the employees. These changes can reduce the non-conformities, expand revenues and result in better use of natural resources.
\end{abstract}

Keywords: Assortments; Planning; Productivity; Measurements; Natural.

Introduction

The Brazilian forest sector has been standing out worldwide due to the technological advances and the knowledge generated by decades of research. Currently, the planted area in Brazil covers 7.84 million hectares. In 2016, the sector's planted forests supplied $91.0 \%$ of the total wood demand for industrial use (Ibá- Brazilian Tree Industry, 2017).

Beyond that, the progressive globalization of the economy triggers gradual demands from consumers, which indicates competitiveness in the industry. In this sense, organizations must inexcusably achieve considerable quality, productivity and efficiency levels to mitigate costs and wastages in order to maximize profits (Martins, 2001).

It is known that for an effective planning and the verification of the economic viability of stands, the timber quantification is fundamental, especially when the quantification is related to the multiple forest uses and, particularly, in forest harvesting and transport activities. Both harvesting and transport activities represent around $50 \%$ of the costs of the raw materials that are consumed by the industry (Machado et al., 2008). Thus, the trend towards optimizing harvesting operations is related to the need for greater productivity along with security, environment and cost matters (LeDoux, 2010).

Similarly, in order to estimate the productivity of stands, the taper functions are important tools used for estimating the total or the merchantable volume of logs in any specified diameter or height along them (Miguel et al., 2011). According to Husch et al. (2003), the shape of the trunk has been the element of many studies in forest measurement. Taper functions allow estimating characteristics of the stands that comprise the volume between points of the shaft, diameter at any point of the trunk and height in a certain diameter (PRODAN et al. 1997). Among the studies that have used taper functions, there are the following: Sharma e Oderwald (2001); Baldwin e Feduccia (1991); Amidon (1984); Biging (1984).

In the same way, Demaerschalk and Kozak (1977) claim that, among the statistical techniques for modeling, the nonsegmented models are the ones that allow combining efficiency with a certain ease of use. The polynomial models are non-segmented models and amidst polynomial equations the fifth-degree ones are used to estimate log volumes based on taper functions. Fifth-degree polynomial 
equations are efficient tools for economic evaluations of forest stands (Fonweban et al., 2011).

In South Brazil, due to the varying and increasing use of Pinus spp. wood (mainly Pinus elliottii Engelm. and Pinus taeda L.), taper functions have been used frequently and the fifth-degree equations are the ones that stand out in the modeling of the tree stem taper (Figueiredo Filho at al., 1996).

Based on the above, the objective of this study was to quantify scenarios considering different stump and prebucking disc heights and to search for alternatives to optimize the mechanized timber harvesting process.

\section{Results and discussion}

\section{Wood wastes}

The descriptive statistical parameters of the volume data $\left(\mathrm{m}^{3}\right)$ which were obtained from the experimental plot, considering the stump and the pre-bucking disc height in the fourth thinning operations, are presented in Table 5.

A total of 26 experimental plots were implemented by calculating the necessary sample intensity with the application of 10 sample units. This has shown that the study was satisfying in estimating the volume in the real situation.

\section{Diametric distribution}

The sum up of the descriptive statistical analysis of the data provided by the company (forest stands destined for the fourth thinning) are shown in Table 6, in terms of the DBH (cm).

In order to know the diametric structure of a forest, it is extremely important to obtain information about the production and the stock of wood, giving support to the decision-making process on the need for forest restoration. The evaluated data were distributed into 7 diametric classes by using the statistical method, as presented in Figure 1 .

Figure 1 shows a higher number of trees concentrated in the larger diametric classes. This concentration is due to the thinning operations that had been carried out until the forest completed 21 years old. The mean DBH of the classes ranges from 21.0 to $44.2 \mathrm{~cm}$. Over time, the frequency distribution has moved to the right.

The same distribution behavior was found by Clutter and Benett (1965) who observed that the diametric distribution curves after thinning operations in Pinus elliottii Engelm. stands moved to the right due to the age of the stands. The authors claim that the number of trees in the lower classes decreased and the number of trees in the upper classes increased during the analyzed period.

Therefore, the selection of trees that had been removed in the previous thinning operations, which happened systematically and selectively in the first two interventions and selectively in the third, benefited the growth of the trees from the upper stratum.

\section{Quantification of the assortments}

Table 7 shows the lower limit, the midpoint, the upper limit, the DBH $(\mathrm{cm})$ and the total height $(\mathrm{m})$ of the trees that have been selected from the forest inventory of wood, considering each diametric class.
The number of logs of each scenario (\%) was obtained by analyzing scenarios with different stump and pre-bucking disc heights, as presented in Figure 2.

The PWP and the PV04 assortments did not present log reduction when considering the different scenarios in the fourth thinning operations. When comparing the scenario S1 to the S2, it can be observed that the stump and the prebucking disc heights did not interfere in most of the quantified assortments. However, the PV01 assortment presented a decrease of $2 \%$ in the number of logs that trigged an increase in the number of logs in the PV02 assortment, which has a higher commercial value.

Moreover, the PWP assortment was not interfered with by the reduction of logs of the PV01 assortment in the scenario S2. This result was different from the one found by Campos and Tavares (2010), who verified a reduction in some of the assortments after harvesting when studying the influence of length and optimization of logs in Pinus pinaster Aiton. According to Foelkel (2015), the volume of the timber measured by the forest inventory of stocks will rarely be reached because the losses of the forest harvesting operations are not being considered.

The scenarios S2 and S3 were the ones that have presented better results regarding the use of higher added value logs. Therefore, the application of one of these scenarios in the company's planning will contribute to better use of the forest plantations by increasing to the maximum the number of logs that can be removed from the shaft, which optimizes the economic value of the wood.

In Table 8, the different scenarios are analyzed according to the changes in stump heights and pre-bucking disc heights. This analysis allows a better view of the losses and gains.

The results in Table 8 show that the assortment with the highest values was the PV02, followed by the PV01 and the PV04. This can be explained by the variation of the log sizes. The diameters of the PV02 assortment were in between 25.0 $\mathrm{cm}$ and $35.0 \mathrm{~cm}$ while the PV04 had diameters over $35.0 \mathrm{~cm}$, considering the age of the trees in the interventions.

When analyzing only the scenarios $\mathrm{S} 1$ and $\mathrm{S} 2$, the results show that the fourth thinning exceeded the production expectations which led to an increase in the final revenue. Although the PV01 assortment presented lower gains, they did not represent losses in the total revenue because the PV02 and PV04 assortments presented a higher proportion than it was expected by the quality control planning and the higher value-added characteristics (wood free of knots and with the largest dimensions).

These results indicate that the operators were able to carry out the activities with a greater efficiency than it was expected by the company. In addition, other factors may have led to these results of the scenario $\mathrm{S} 2$ as the low slope of the fields in the areas of the evaluated interventions. According to Stampfer et al. (1999), the slope of the field influences the Harvester productivity.

Furthermore, other factors may explain the conformity with the fourth-thinning planning like the low diameter of the trees to be harvested, the lower individual tree volumes and the low slope of the stands.

A loss of timber retained on the stumps and the pre-bucking discs of $0.08 \mathrm{t} \mathrm{ha}^{-1}$ was observed by comparing the scenario S1 to the S3. Similar studies have found similar results. Fink et al. (2008), when analyzing the amount of wood retained in stumps on semi-mechanized harvesting operations, 
Table 1. Characteristics of the fourth thinning.

\begin{tabular}{lc}
\hline Characteristics & Fourth thinning \\
\hline Species & Pinus elliottii \\
Stand age (years) & 21 \\
Total area (ha) & 32.8 \\
Planting distance $(\mathrm{m})$ & $2.0 \times 3.0$ \\
Diameter at breast height $(\mathrm{cm})$ & 31.3 \\
Average height $(\mathrm{m})$ & 24.6 \\
Individual average volume $\left(\mathrm{m}^{3}\right)$ & 0.82 \\
Expected production $\left(\mathrm{m}^{3} / \mathrm{ha}^{3}\right)$ & 120.0 \\
Declivity (o) & $0-5$ \\
Density withdrawal $(\mathrm{N} / \mathrm{ha})$ & 146 \\
\hline \multicolumn{2}{c}{ Source: Adapted by the author from the Forest Company (2018). }
\end{tabular}

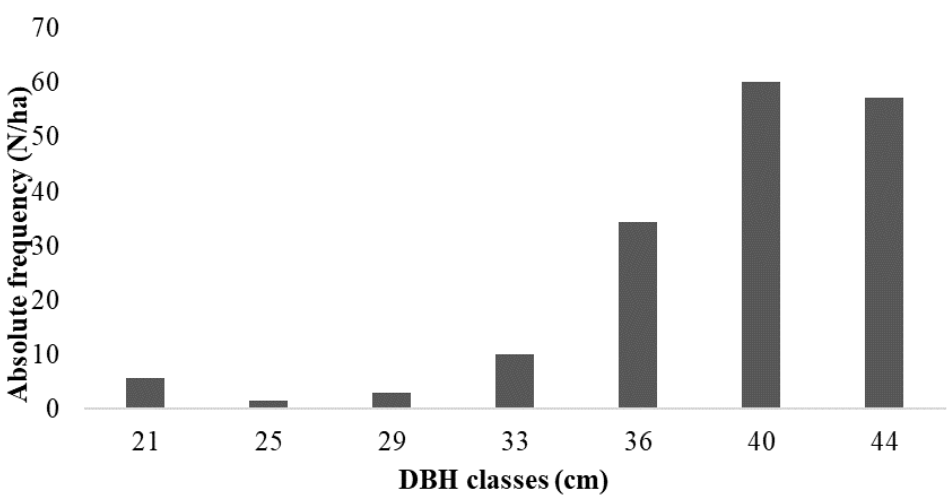

Fig 1. Absolute frequency $(\mathrm{N} / \mathrm{ha})$ distribution of the $\mathrm{DHB}(\mathrm{cm})$ classes of the trees intended to the fourth thinning intervention.

Table 2. Classification of the multiple uses of wood from the company's Pinus spp. forests.

\begin{tabular}{lccccc} 
Assortment & \multicolumn{2}{c}{ Diameter $(\mathrm{cm})$} & Length $(\mathrm{m})$ & $\begin{array}{c}\text { Price of wood with bark } \\
\text { (USD per ton) }\end{array}$ & Possible use \\
\cline { 2 - 3 } & Lowest & Highest & & & \\
\cline { 2 - 4 } PWP & 8 & 18 & 2.7 & 10.76 & Energy \\
PV01 & 18 & 25 & 2.7 & 32.02 & Cellulose \\
PV02 & 25 & 35 & 2.7 & 53.01 & Sawn wood \\
PV04 & 35 & 41,9 & 2.7 & 72.66 & Veneer wood \\
PV06 & Over 42 & - & 2.7 & 94.72 & Veneer wood \\
\hline Source: Forest company, 2018. & & & & &
\end{tabular}

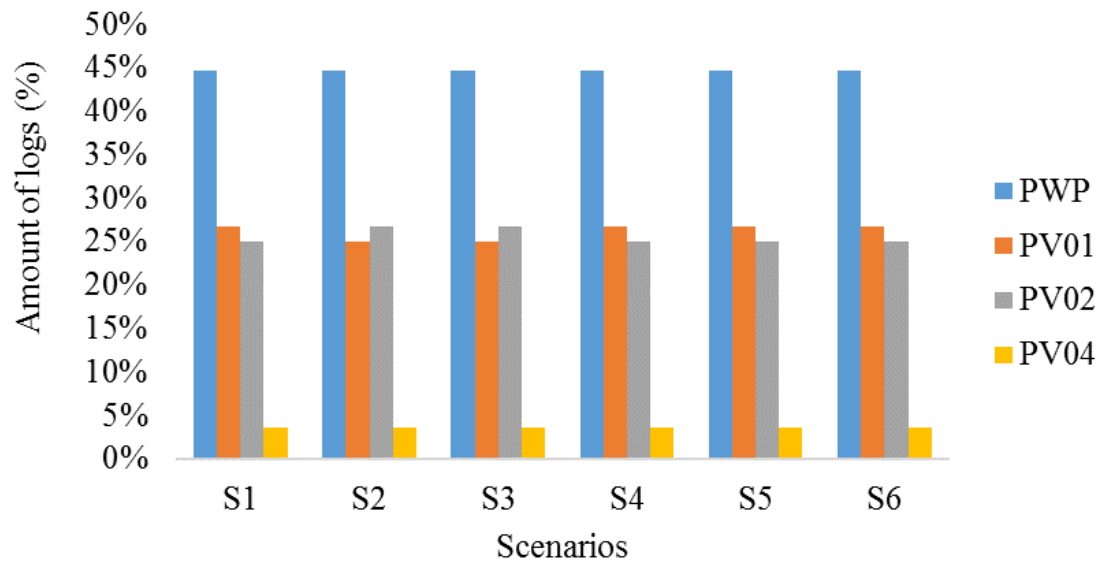

Fig 2. Amount of logs (\%) for the different assortments in each scenario. 
Table 3. Statistical parameters and coefficients of the adjusted taper function for the variable $d i$.

\begin{tabular}{|c|c|c|c|c|c|c|c|c|c|}
\hline \multirow[b]{2}{*}{ Species } & \multirow[b]{2}{*}{ Author } & \multicolumn{6}{|c|}{ Coefficient } & \multirow[b]{2}{*}{$R^{2} a j$} & \multirow[b]{2}{*}{$\mathrm{S}_{\mathrm{yx}} \%$} \\
\hline & & $\beta 0$ & $\beta 1$ & $\beta 2$ & $\beta 3$ & $\beta 4$ & $\beta 5$ & & \\
\hline Pinus elliottii & Schoffer & 1.07 & 3.40 & 16.83 & 39.42 & 40.57 & 15.85 & 0.97 & 6.12 \\
\hline
\end{tabular}

Source: Forest Company.

Table 4. Stump and pre-bucking heights $(\mathrm{cm})$ considering different scenarios in the fourth thinning operations.

\begin{tabular}{lll}
\hline \multirow{2}{*}{ Scenarios } & Height $(\mathrm{cm})$ & \\
\cline { 2 - 3 } & Stump & Pre-bucking \\
\hline 1 & 15.0 & 10.0 \\
2 & Real & Real \\
3 & 10.0 & 5.0 \\
4 & 20.0 & 15.0 \\
5 & 25.0 & 20.0 \\
6 & 35.0 & 20.0 \\
\hline
\end{tabular}

Table 5. Statistical information of the volume data $\left(\mathrm{m}^{3}\right)$ of the experimental plots considering stump and pre-bucking disc heights in the fourth thinning interventions.

\begin{tabular}{lll}
\hline \multirow{2}{*}{ Volume } & \multicolumn{2}{l}{ Fourth thinning } \\
\cline { 2 - 3 } & Stump & Pre-bucking disc \\
\hline Minimum $\left(\mathrm{m}^{3}\right)$ & 0.00038 & 0.00010 \\
Mean $\left(\mathrm{m}^{3}\right)$ & 0.00071 & 0.00032 \\
Maximum $\left(\mathrm{m}^{3}\right)$ & 0.00098 & 0.00073 \\
Standard deviation $\left(\mathrm{m}^{3}\right)$ & 0.00016 & 0.00023 \\
Coefficient of variation $(\%)$ & 22.81 & 22.72 \\
Standard error of the estimate $\left(\mathrm{m}^{3}\right)$ & 0.00003 & 0.00007 \\
Number of plots necessary & 23 & 25 \\
\hline
\end{tabular}

Table 6. Statistical information of the data of the stands destined for the fourth thinning.

\begin{tabular}{ll}
\hline Statistics & DBH \\
\hline Minimum $(\mathrm{cm})$ & 21.0 \\
Mean $(\mathrm{cm})$ & 38.2 \\
Maximum $(\mathrm{cm})$ & 46.0 \\
Standard deviation $(\mathrm{cm})$ & 5.0 \\
Coefficient of variation $(\%)$ & 16.39 \\
Sampling error $(\mathrm{cm})$ & 0.49 \\
\hline
\end{tabular}

Table 7. Lower limit, midpoint, upper limit, $\mathrm{DBH}(\mathrm{cm})$ and total height $(\mathrm{m})$ for each diametric class of the trees selected from the forest inventory of wood.

\begin{tabular}{llllll}
\hline \multirow{2}{*}{\begin{tabular}{llll} 
Classes \\
\cline { 3 - 5 }
\end{tabular}} & Lower limit $(\mathrm{cm})$ & Midpoint $(\mathrm{cm})$ & $\begin{array}{l}\text { Upper limit } \\
(\mathrm{cm})\end{array}$ & Trees & $\begin{array}{l}\text { Total height } \\
(\mathrm{m})\end{array}$ \\
\hline 1 & 19.1 & 21.0 & 22.9 & 21.0 & 22.7 \\
2 & 23.0 & 24.9 & 26.8 & 25.0 & 24.1 \\
3 & 26.9 & 28.7 & 30.6 & 29.0 & 23.8 \\
4 & 30.7 & 32.6 & 34.5 & 33.0 & 26.8 \\
5 & 34.6 & 36.5 & 38.4 & 37.0 & 26.7 \\
6 & 38.5 & 40.4 & 42.2 & 40.0 & 24.6 \\
7 & 42.3 & 44.2 & 46.1 & 44.0 & 23.5 \\
\hline
\end{tabular}

Table 8. Quantification of the assortments in tons per hectare ( $\left.\mathrm{t} \mathrm{ha} \mathrm{C}^{-1}\right)$ and monetary value per hectare ( $\left.\mathrm{R} \$ \mathrm{ha}^{-1}\right)$ for each assortment in the different analyzed scenarios.

\begin{tabular}{llll}
\hline Scenarios & Assortments & t ha-1 $^{-1}$ & \$ ha-1 \\
\hline \multirow{4}{*}{1} & PWP & 21.19 & 231.04 \\
& PV01 & 34.26 & 1111.56 \\
& PV02 & 57.26 & 3075.26 \\
& PV04 & 12.63 & 929.77 \\
\cline { 2 - 4 } 2 & Total & 125.35 & 5347.62 \\
\hline \multirow{2}{*}{2} & PWP & 21.44 & 233.80 \\
& PV01 & 31.37 & 1017.77
\end{tabular}




\begin{tabular}{llll} 
& PV02 & 60.43 & 3245.22 \\
3 & PV04 & 12.71 & 935.18 \\
\cline { 2 - 4 } 3 & Total & 125.95 & 5431.97 \\
\hline \multirow{4}{*}{4} & PWP & 21.46 & 233.98 \\
& PV01 & 31.44 & 1019.89 \\
& PV02 & 60.43 & 3245.22 \\
& PV04 & 12.71 & 935.18 \\
\cline { 2 - 4 } & Total & 126.03 & 5434.27 \\
\hline \multirow{4}{*}{5} & PWP & 20.84 & 227.21 \\
& PV01 & 33.94 & 1101.03 \\
& PV02 & 56.83 & 3051.81 \\
& PV04 & 12.49 & 919.34 \\
\cline { 2 - 4 } & Total & 124.09 & 5299.39 \\
\hline \multirow{4}{*}{6} & PWP & 20.46 & 223.11 \\
& PV01 & 33.62 & 1090.62 \\
& PV02 & 3028.98 \\
& PV04 & 56.40 & 909.42 \\
\cline { 2 - 4 } & Total & 12.36 & 5252.12 \\
\hline
\end{tabular}

observed losses of $0.067 \mathrm{tha}^{-1}$. Serpe (2017) found losses of $0.23 \mathrm{t} \mathrm{ha}^{-1}$ in mechanized harvesting operations using a directional Feller. These results indicate that losses can occur in the forest harvesting process regardless of the modules that are used in the operations.

The amount of wood desired by the company is in accordance with the objectives of the harvesting operation plan for the scenario S2. But, considering the performance of the fourth thinning operations, the scenario S3 presented the highest revenues. Thus, in order to optimize the process, the company must seek to change the planning of its specifications and the training of its employees.

\section{Materials and Methods}

\section{Location and description of the study area}

This study took place in areas of a forest company located in Campo Belo do Sul, Santa Catarina, Brazil. The average elevation of the city is $950 \mathrm{~m}$ and the annual precipitation varies from 1.300 to $2.400 \mathrm{~mm}$. Most of the city's soil is classified as a Hapludox but, in lands of a greater slope, both Inceptisol and Dystrophic Litholic soils can be found. The company is a primary sector business which operates in timber management, marketing, and in the planting of Pinus spp., Eucalyptus spp. and Araucaria angustifolia (Bertol.) Kuntze forests.

Thinning operations vary according to the forest development. Before the clear-cutting of the evaluated plantations, four to six thinning operations are usually carried out by the company. In keeping with the company's demand, the plantations were evaluated after the fourth thinning (forest age 25) (Table 1).

The company carried out the first and the fourth thinning systematically, when the forest ages were from 7 to 8 and from 11 to 12, respectively. First, the trees from the fifth line of the forest stands were cut down and then, selectively, they were removed in order to allow a better development of the remaining trees. Both operations were done when the basal area of the stands overcame $40 \mathrm{~m}^{2} \mathrm{ha}^{-1}$.

Subsequent thinning operations followed the selective way described above and considered the forest development. In addition, the forest stands had undergone pruning before the interventions to obtain high-quality wood without the presence of knots.

For this study, two modules of cut-to-length mechanized harvesting were evaluated. The harvesting operations were carried out by the following forest machines, a Harvester, a Forwarder, and a Loader.

\section{Simulation of scenarios}

In order to simulate scenarios, the data were collected in two different ways. The desired stump and pre-bucking disc heights were verified according to the company's specifications (Scenario 1). The Harvester is allowed to work with stump heights and pre-bucking disc heights of up to 15 $\mathrm{cm}$ and $10 \mathrm{~cm}$, respectively.

Then, frequency distribution tables (FDT) were made by using the company's inventory of wood stock and considering the diameter at breast height (DBH) of the trees that were assigned for the fourth thinning. The DBH data were grouped into classes according to the Sturges' method and the descriptive statistics was used for the data analysis. In this way, the following variables were obtained: number of classes, amplitude, the lower limit (LL), the upper limit $(\mathrm{UL})$, absolute frequency (AF) and relative frequency (RF).

\section{Classification of the assortments}

There are a variety of uses for the timber produced by the company. For this study, the assortments analyzed were the ones that, according to the company's classification, are classified as logs without knots, "PV" (Pinus veneer) and "PWP" (Pinus for the wood process). The minimum commercial diameter considered was $8 \mathrm{~cm}$ and the fixed log 
length was $2.70 \mathrm{~m}$ because they represent most of the PV assortments established by the company. The timber products available for marketing were set according to the company's classification, as showed in Table 2.

\section{Collection of the real situation data}

The collection of the fourth-thinning data in a real situation (Scenario 2) was carried out by using 10 sampling units, considering the fixed area method and the random sampling process. The area of the sampling units was $400 \mathrm{~m}^{2}$ and they had a square shape $(20 \mathrm{~m} \times 20 \mathrm{~m})$, according to Durigan (2003). The diameter and the height of the stumps (in two different positions) and the pre-bucking discs (that were found in the sampling units) were measured with a tape measure.

Later, the final number of samples for each intervention was given by the Equation 1, as suggested by Sanqueta et al. (2009) for an infinite population, in function of the total volume of the stumps and the pre-bucking $\operatorname{discs}\left(\mathrm{m}^{3}\right)$.

$n=\frac{t^{2 * C V} \%^{2}}{E \%^{2}}$

In which:

$n$ is the number of necessary sample;

$t$ is the $t$ distribution value for a significance level at 95\%;

CV\% is the coefficient of variation (\%);

$E \%$ is the maximum error allowed (10\%).

Afterward, the descriptive statistics were used to analyze the data with a view to contributing to the interpretation of the results.

\section{Estimation of the assortments}

Taper functions were used for estimating the assortments in different scenarios by obtaining the tree stem diameters at different heights, the partial tree stem volumes and the total tree stem volumes. To that end, a tree obtained from the forest inventory of wood stock, with the DBH compatible with each diameter class, was defined.

In order to obtain the diameter at any specific height, it is necessary to isolate the di variable from the diameter at breast height (DBH) and the total height (h) values in the Schöepfer's function (SCHÖEPFER, 1966), as shown in Equation (2).

$\frac{d i}{D B H}=\beta_{0}+\beta_{1}\left(\frac{h i}{h}\right)+\beta_{2}\left(\frac{h i}{h}\right)^{2}+\beta_{3}\left(\frac{h i}{h}\right)^{3}+\beta_{4}\left(\frac{h i}{h}\right)^{4}+$ $\beta_{5}\left(\frac{h i}{h}\right)^{5}+\varepsilon_{i}(2)$

In which:

$d i$ is the estimated diameter $(\mathrm{cm})$;

$h i$ is the height along the trunk (m);

$D B H$ is the diameter at breast height $(\mathrm{cm})$;

$h$ is the total height $(\mathrm{m})$;

$b_{0}, b_{1}, b_{2}, b_{3}, b_{4}$, and $b_{5}$ are the equation parameters to be estimated;

$\varepsilon_{i}$ is the error of estimate.

Afterward, the function of the sectional area was integrated, according to Schöepfer (1966) and considering the desired upper ( $h 2$ ) and lower ( $h 1)$ limits, to obtain the volume over bark $(v)$. The Equation 6 allows obtaining the commercial assortments and volumes that correspond to any portion of the tree and/or the total volume.

$$
\begin{aligned}
& v=K * D B H\left[\frac{1}{11} C_{5}^{2} h_{i}^{11}+\frac{1}{5} C_{4} C_{5} h_{i}^{10}+\frac{1}{9}\left(2 C_{5} C_{3}+C_{4}^{2}\right) h_{i}^{9}+\right. \\
& \frac{1}{8}\left(2 C_{3} C_{4}+2 C_{5} C_{2}\right) h_{i}^{8}+\frac{1}{7}\left(2 C_{2} C_{4}+2 C_{5} C_{1}+C_{3}^{2} h_{i}^{7}+\right. \\
& \frac{1}{6}\left(2 C_{1} C_{4}+2 C_{3} C_{2}+2 C_{5} C_{0}\right) h_{i}^{6}+\frac{1}{5}\left(C_{2}^{2}+2 C_{4} C_{0}+\right. \\
& \left.2 C_{1} C_{3}\right) h_{i}^{5}+\frac{1}{4}\left(2 C_{3} C_{0}+2 C_{1} C_{2}\right) h_{i}^{4}+\frac{1}{3}\left(C_{1}^{2}+2 C_{2} C_{0}\right) h_{i}^{4}+ \\
& \left.C_{0} C_{1} h_{1}^{2}+C_{0}^{2} h_{i}\right]
\end{aligned}
$$

In which:

$v$ is the assortment's volume $\left(\mathrm{m}^{3}\right)$;

$K$ is $\pi / 40000$;

$D B H$ is the diameter at breast height $(\mathrm{cm})$;

$C$ is an undetermined constant and $h i$ is the height along the trunk $(m)$.

Finally, right after the quantification of the assortments the volumes were transformed into mass and quantified because the final product is marketed in tons. Therefore, a conversion factor (0.828) was used for the genus Pinus with bark. In addition to the quantification of the logs, the estimation of the assortments was obtained in tons per hectare ( $\mathrm{t} \mathrm{ha} \mathrm{H}^{-1}$ ) and in monetary value per hectare (USD ha1).

\section{Methods and adjustment selection}

The Schöepfer's model (Fifth Degree Polynomial - 1966) is used by the company and, therefore, the company has provided the information needed for the evaluation of the statistical adjustment and accuracy, in accordance with the parameters described by Draper and Smith (1966).

The statistical parameters of the fifth degree polynomial of the variable $d i$ (diameter over bark), in centimeters, with the adjusted coefficient of determination $\left(R^{2} a j\right)$ and the standard error of estimate (Sxy\%), in percentage, are presented in Table 3.

\section{Scenarios}

In order to assess the effects of the mechanized harvesting process considering the different stump and pre-bucking disc heights, the number of logs and assortments obtained along the trunk were simulated, as shown in Table 4.

The situation defined by the company in its planning was considered and applied to the scenario 1 (S1), that is, stump heights and pre-bucking disc heights up to 15 and $10 \mathrm{~cm}$, respectively. Aiming at achieving an effective quality control, the company presents in its planning the specifications for the several forest harvesting operations. In fourth thinning operations, the Harvester is allowed to work with stump heights and pre-bucking disc heights of up to $15 \mathrm{~cm}$ and 10 $\mathrm{cm}$, respectively.

The scenario 2 (S2) was obtained through the measurement of the stump and the pre-bucking disc heights in the real situation, with the application of sampling units. The stump heights up to $10 \mathrm{~cm}$ and the pre-bucking heights up to $5 \mathrm{~cm}$ were applied to the scenario 3 (S3). The stump and the prebucking disc heights higher than the ones specified by the 
company were applied to the other scenarios (S4, S5, and S6).

Later, the estimation of the assortments in tons per hectare $\left(\mathrm{t} \mathrm{ha} \mathrm{a}^{-1}\right)$ and in monetary value per hectare (USD ha-1) was obtained, considering the price of wood with bark (USD $\mathrm{t}^{-1}$ ) for each assortment.

\section{Conclusion}

In the scenario S2, the company exceeded the production expectations and the planned economic profits by performing operations with higher than expected forest returns. However, these activities can still be optimized with the implementation of the scenario $\mathrm{S} 3$, that is, with stump heights and pre-bucking disc heights of $10 \mathrm{~cm}$ and $5 \mathrm{~cm}$, respectively. A cut closer to the ground would reduce the rework of grinding tree stumps, resulting in better performance and lower costs. Nevertheless, these kinds of situations must be evaluated considering the damage risks of the forest machines. Likewise, future surveys and measures can be made to reduce failures in the mechanized forest harvesting activities along with the alignment of machines and training of the operators.

\section{Acknowledgments}

Foundation for the Support of the Scientific and Technological Research of Santa Catarina State (FAPESC).

\section{References}

Amidon EL (1984) A general taper functional form to predict bole volume for five mixed-conifer species in California. Forest Science, Washington. 30(1): 166-171.

Baldwin JRVC, Feduccia DP (1991) Compatible tree-volume and upper-stem diameter equations for plantation Loblolly Pines in the West Gulf region. Southern Journal of Applied Forestry. 15(2): 92-97.

Biging GS (1984) Taper equations for second-growth mixed conifers of Nothern California. Forest Science, Washington. 30(4):1103-1117.

Campos C, Tavares M (2010) Influência do comprimento e origem do toro na optimização do aproveitamento e do valor de rolos de pinho bravo. Silva Lusitana, Oeiras. 18(1): 123-132.

Clutter JL, Benett FA (1965) A diameter distribution in oldfield slash pine plantations. Georgia Forest Research Council Report. 13: 1-9.

Demaerschalk JP, Kozak A (1977) The whole-bole system: a conditional dual-equation system for precise prediction of tree profiles. Canadian Journal of Forest Research, Ottawa. 7(3): 488-497.

Draper NR, Smith H (1966) Applied regression analysis. New York: Jonh Willey e Sons. 407p.

Durigan G (2003) Métodos para análise de vegetação arbórea. Métodos de Estudos em Biologia da Conservação e Manejo da Vida Silvestre. Curitiba: UFPR; Boticário Foundation of Nature Protection. 455-479p.
Figueiredo FA, Borders BE, Hitch KL (1996) Taper equations for Pinus taeda plantations in Southern Brazil. Forest Ecology and Management, Amsterdam. 83: 39-46.

Fink JL, Valério AV, Watzlawick AF, Lisboa GS, Silvestre $R$ (2008) Caracterização da altura de corte em desbaste de Pinus elliottii com 6 anos. Available from: http://www.unicentro.br/pesquisa/anais/seminario/pesqu isa2008/pdf/artigo_731.doc Accessed on 20 out. 2017.

Foelkel CO (2015) Medição da madeira na forma de toras empilhadas. Eucalyptus Newsletter, 48p.

Fonweban J, Gardiner B, Macdonald E, Auty D (2011) Taper functions for Scots pine (Pinu sylvestris, L.) and Sitka spruce (Picea sitchensis (Bong.) Carr.). Northern Britain. Forestry. 84: 49-60.

Husch B, Beers TW, Kershaw Junior JA (2003) Forest mensuration. 4 ed. Malabar: Krieger Publishing Company. $443 \mathrm{p}$.

Ibá - Indústria Brasileira de árvores (2016) Available from: $<$ http://iba.org/images/shared/Biblioteca/IBA_RelatorioAn ual2016_pdf>. Accessed on 20 jun. 2017.

LeDoux CB (2010) Mechanized systems for harvesting eastern hardwoods. Newtown Square: U.S. Department of Agriculture, Forest Service, Northern Research Station. $13 p$.

Machado CC, Silva EM, Pereira RS (2008) O setor florestal brasileiro e a colheita florestal. In: Machado CC (3ed) Colheita florestal, Viçosa, Minas Gerais: 15-42p.

Martins E (2001) Contabilidade de custos. Atlas. (8ed), São Paulo.

Miguel EP, Machado AS, Figueiredo FA, Arce JE (2011) Modelos polinomiais para representar o perfil e o volume do fuste de Eucalyptus urophylla na região norte do Estado de Goiás. Revista Floresta, Curitiba, Paraná. 41(2): 355368.

Prodan M, Peters R, Cox F, Real P (1997) Mensura Forestal. San José: Instituto Interamericano de Cooperación para la Agricultura (IICA). 586p.

Rojo A, Perales X, Sánchez-Rodríguez F, González-Alvarez JG, Gadow K (2005) Stem taper functions for maritime pine (Pinus pinaster Ait.) in Galicia (Nortwestern Spain). European Journal of Forest Research, Dordrecht, 124(3): 177-186.

Sanquetta CR, Watzlawick LF, Dalla Corte AP, Fernandes LV (2006) Inventários Florestais: Planejamento e Execução. Curitiba: 270p.

Schoepfer W (1966) Automatisierung des Massem, Sorten und Wertberechnung stenender Waldbestande Schriftenreihe Bad. Wurtt-Forstl.

Serpe EL, Figueiredo AF, Arce JE (2018) Perdas volumétricas relativas à colheita florestal e seus reflexos econômicos. Biofix Scientific Journal. 3(1): 172-176.

Sharma M, Oderwald RG (2001) Dimensionally compatible volume and taper equations. Canadian Journal of Forest Research, Ottawa. 31(5): 797-803.

Stampfer K, Loschek J (1999) Harvester operations increase the productivity of cable extraction systems. Osterreicchische Forstzeitung (Arbeit im Wald). 11(2): 4-6. 